\title{
Screening of Different Rootstocks of Pomegranate (Punica granatum L.) against Root Knot Nematode
}

\author{
Dipak Kumar B. Ahire* \\ Department of Horticulture, Mahatma Phule Krishi Vidyapeeth, Rahuri-College of \\ Agriculture, Nandurbar, Dist. Nandurbar, Pin - 425412, Maharashtra, India \\ *Corresponding author
}

\section{A B S T R A C T}

\section{Keywords}

neutraceutical values, Punica granatum $\mathrm{L}$, planting material, Pomegranate wilt

Article Info

Accepted:

12 May 2021

Available Online:

10 June 2021
The study on "Screening of different rootstocks of pomegranate (Punica granatum L.)" against root knot nematode" was undertaken with a view to screen the various rootstocks under sick soil (pot culture) with view to identify root knot nematode tolerant/resistant pomegranate rootstocks. Eleven rootstocks genotypes were screened and among these rootstocks four viz., Daru, Jodhpur Red, Jallore Seedless and Bedana Suri were found to be moderately resistant to root-knot nematodes Meloidogyne incognita. The lowest mortality (13.33\%) was recorded in two rootstocks viz., Bedana Suri and Yercaud The highest mortality (40.00\% each) was recorded in Alandi. The mortality ranged from 13.33-40.00\%.The average range of nematode galls was 25.3336.00. The minimum nematode galls (25.33) were recorded in Daru. However, the maximum nematode galls (36.00) were recorded in the rootstock Yercaud. The final minimum (3286.67) nematode count/pot was recorded in the rootstock Daru $\left(\mathrm{R}_{11}\right)$. However, the maximum (5860.00) nematode count/pot was recorded in the rootstock Kandhari $\left(\mathrm{R}_{4}\right)$. The final root-knot nematode count/pot ranged from 3286.67- 5860.00 at the end of the experiment (180 days after sowing). Thus, it is concluded that the rootstocks viz., Daru, Jodhpur Red, Jallore Seedless and Bedana Suri were found to be moderately resistant to root-knot nematode.

\section{Introduction}

Pomegranate (Punica granatum L.) from Punicaceae family is gaining lot of attention world over, due to its high economic and neutraceutical values. India is the largest pomegranate producer in the world (13.45 lakh tonnes). Area under this crop is growing irrespectively in different soil conditions and agro climatic conditions. In addition to this environmental factor such as soil $\mathrm{pH}$ (Robinson et al., 1987) will also be linked to the development of disease complex.

However, Vegetative propagated planting material, excess use of fertilizers soil types, quality of water, high density planting and climate change seems to initiate different 
problems like wilt/decline in pomegranate cultivation.

Pomegranate wilt is associated with nematodes and fungus. It is also thought that, easier infection of pathogen/nematode is through open area like in cutting/base part of cutting/gooty/on succulent roots. Rootstocks have been used in fruit crops to protect against soil born diseases and pests since long time. Development of tap and secondary root is possible through seedling propagation. This may help in minimising the root exposure in root rhizosphere and their by limiting infection of pathogen and root knot nematode.

Thus, with view to study the resistance to root-knot nematode by using different rootstocks the present investigation entitled "Screening of different rootstocks of pomegranate (Punica granatum L.)" was conducted.

\section{Materials and Methods}

The studies on "Screening of different rootstocks of pomegranate (Punica granatum L.)" against root knot nematode was undertaken with a view to identify wilt resistant/tolerant rootstocks of pomegranate (Punica granatum L.) against root-knot nematode, Meloidogyne incognita.

The investigations was carried out at PGI, glasshouse, Department of Plant Pathology and Entomology, MPKV., Rahuri DistAhmednagar during 2013-2015. Total eleven treatments, three replication, 25 numbers of seedling @ treatment and CRBD were used

Eleven pomegranate rootstocks were explored for the studies VIZ., Ganesh $\left(\mathrm{R}_{1}\right)$ Bedana Suri, $\left(\mathrm{R}_{2}\right)$ Alandi, $\left(\mathrm{R}_{3}\right)$ Kandhari $\left(\mathrm{R}_{4}\right)$, Jallore Seedless $\left(\mathrm{R}_{5}\right)$, Jodhpur Red $\left(\mathrm{R}_{6}\right)$, Patna-5( $\left.\mathrm{R}_{7}\right)$, Muscat $\left(\mathrm{R}_{8}\right)$, Yercaud $\left(\mathrm{R}_{9}\right)$, Bedana Sedana $\left(\mathrm{R}_{10)}\right.$ \& Daru $\left(\mathrm{R}_{11}\right)$.

\section{Soil sterilization}

Medium black soil mixed with FYM in 3:1 proportion. The mixture after sieving was steam sterilized at the pressure of $6.75 \mathrm{~kg} / \mathrm{cm}^{2}$ for four hours in a soil sterilizer with boiler. The sterilized soil mixture was filled in disinfected new plastic pots/container with 15 $\mathrm{cm}$ diameters and $10 \mathrm{~kg}$ capacity was used.

Roots bark and stem showing wilt symptoms pomegranate plants were collected from different orchards for isolation of the nematodes.

The pure culture of nematode was maintained in earthen pots (Pela) in glasshouse. Tomato crop was grown in earthen pots to maintain and multiply the nematodes. The culture thus maintained was used in further studies.

\section{Extraction of nematodes}

The nematodes were extracted from earlier grown tomato pots, by Cobb's Decanting and Sieving Method (Cobb, 1918) and were used for further studies.

\section{Nematode inoculation}

The nematode suspension was prepared by using Cobb's decanting and sieving method and was inoculated by making holes in pot soil.

\section{Screening of various pomegranate rootstocks against root-knot nematode, Meloidogyne incognita}

Pots were sterilized with 4 per cent formaldehyde (Formalin 40 EC). Then sterilized pots were filled with inoculated mixture and rootstock seeds were sown. After establishment of seedlings 500 freshly hatched second stage nematode juveniles was inoculated to each pot. 
All observations pertaining to this study were recorded time to time.

\section{Results and Discussion}

The results obtained in present investigations are presented under suitable headings.

\section{Screening for Root Knot Nematode}

Screening of different pomegranate rootstocks or their reaction to Meloidogyne incognita is presented in Table 1.

Disease complexes involving fungi and nematode have gained momentum in the recent year. The data on reaction of different pomegranate rootstocks/genotypes to nematode, Meloidogyne incognita is presented under suitable heading.

\section{Incubation period}

During screening the typical wilting symptoms such as yellowing of leaves, shedding of leaves and wilting of branches of plants were observed. The late wilt symptoms (16.33 months) was recorded in rootstock Jallore Seedless $\left(R_{5}\right)$ and it was at par with Bedana Suri $\left(\mathrm{R}_{2}\right)$, Jodhpur Red $\left(\mathrm{R}_{5}\right)$ and Daru $\left(\mathrm{R}_{11}\right)$ (16.00 months each), while the earlier symptoms (12 months) were observed in Alandi $\left(\mathrm{R}_{3}\right)$, Patna-5 $\left(\mathrm{R}_{7}\right)$ and Muscat $\left(\mathrm{R}_{8}\right)$. The incubation period ranged from 12-16 months.

\section{Mortality (\%)}

The lowest mortality (13.33\%) was recorded in two rootstocks viz., Bedana Suri $\left(\mathrm{R}_{1}\right)$ and Yercaud $\left(\mathrm{R}_{9}\right)$ and it was at par with Daru $\left(\mathrm{R}_{11}\right)$ $(16.67 \%)$ and Jallore Seedless $\left(\mathrm{R}_{5}\right)(20.00 \%)$. However, the highest mortality (40.00\% each) was recorded in Alandi $\left(\mathrm{R}_{3}\right)$ and Muscat $\left(\mathrm{R}_{8}\right)$ and it was at par with Ganesh $\left(\mathrm{R}_{1}\right)$ and Patna-5 $\left(\mathrm{R}_{7}\right) \quad(36.67 \%$ each$)$, Kandhari $\left(\mathrm{R}_{3}\right)$ and Bedana Sedana $\left(\mathrm{R}_{10}\right) \quad(33.33 \%$ each $)$. The mortality ranged from $13.33-40.00 \%$.

\section{Average number of roots/plant}

The number of roots of different rootstocks at $19^{\text {th }}$ month is presented in Table 2.

The maximum average number of roots (16.00) was recorded in Bedana Suri $\left(\mathrm{R}_{2}\right)$ and Alandi $\left(\mathrm{R}_{3}\right)$ and it was at par with Ganesh $\left(\mathrm{R}_{1}\right)$ (15.33) and Kandhari $\left(\mathrm{R}_{4}\right)$ (15.00). However, the minimum number of roots (13.67) was recorded in rootstock Daru $\left(\mathrm{R}_{11}\right)$ and it was at par with rest of the six rootstocks viz., Patna-5 $\left(\mathrm{R}_{7}\right)$, Yercaud $\left(\mathrm{R}_{9}\right)$ and Bedana Sedana $\left(\mathrm{R}_{10}\right)$ (14.00 each), Jallore Seedless $\left(\mathrm{R}_{5}\right)$ and Muscat $\left(\mathrm{R}_{8}\right) \quad(14.33$ each $)$ and Jodhpur Red $\left(\mathrm{R}_{6}\right)(14.67)$.

\section{Average number of nematode galls/plant}

The average range of galls was 25.33-36.00 (Table 2). The minimum nematode galls (25.33) per plant were recorded in Daru $\left(R_{11}\right)$ and it was at par with Jodhpur Red $\left(\mathrm{R}_{6}\right)$ (26.00) and it was followed by Jallore Seedless $\left(R_{5}\right)$ (27.33). However, the maximum nematode galls (36.00) were recorded in rootstock Yercaud $\left(\mathrm{R}_{9}\right)$ it was followed by rootstocks Patna-5 $\left(\mathrm{R}_{7}\right)(34.67)$ and Bedana Sedana $\left(\mathrm{R}_{10}\right)$ (34.00).

\section{Root-knot nematode (M. incognita) population}

The root-knot nematode ( $M$. incognita) was recorded by Cobb's decanting and sieving method. The initial count at the time of inoculation was 500. At the end of the experiment the final root-knot nematode count/pot ranged from 3286.67- 5860.00. 
Table.1 Incubation period and pathogenicity/mortality of different pomegranate rootstocks against nematode Meloidogyne incognita

\begin{tabular}{|c|c|c|}
\hline Treatment & $\begin{array}{l}\text { Incubation period } \\
\text { (months) }\end{array}$ & Mortality (\%) at $19^{\text {th }}$ month) \\
\hline \multicolumn{3}{|l|}{ Rootstocks } \\
\hline Ganesh $\left(\mathbf{R}_{1}\right)$ & $\begin{array}{c}14.67 \\
(22.52)\end{array}$ & $\begin{array}{c}36.67 \\
(37.22)\end{array}$ \\
\hline Bedana Suri $\left(\mathbf{R}_{2}\right)$ & $\begin{array}{c}16.00 \\
(23.57)\end{array}$ & $\begin{array}{c}13.33 \\
(21.14)\end{array}$ \\
\hline Alandi $\left(\mathbf{R}_{3}\right)$ & $\begin{array}{c}12.00 \\
(20.27)\end{array}$ & $\begin{array}{c}40.00 \\
(39.15)\end{array}$ \\
\hline Kandhari $\left(\mathbf{R}_{\mathbf{4}}\right)$ & $\begin{array}{c}12.67 \\
(20.85)\end{array}$ & $\begin{array}{c}33.33 \\
(35.22)\end{array}$ \\
\hline Jallore Seedless $\left(\mathbf{R}_{5}\right)$ & $\begin{array}{c}16.33 \\
(23.84)\end{array}$ & $\begin{array}{c}20.00 \\
(26.07)\end{array}$ \\
\hline Jodhpur Red $\left(\mathbf{R}_{6}\right)$ & $\begin{array}{c}16.00 \\
(23.58)\end{array}$ & $\begin{array}{c}\mathbf{3 0 . 0 0} \\
(33.00)\end{array}$ \\
\hline Patna-5 $\left(\mathbf{R}_{7}\right)$ & $\begin{array}{c}12.00 \\
(20.27)\end{array}$ & $\begin{array}{c}36.67 \\
(37.14)\end{array}$ \\
\hline Muscat $\left(\mathbf{R}_{8}\right)$ & $\begin{array}{c}12.00 \\
(20.27)\end{array}$ & $\begin{array}{c}40.00 \\
(39.15)\end{array}$ \\
\hline Yercaud ( $\left.\mathbf{R}_{9}\right)$ & $\begin{array}{c}14.00 \\
(21.97)\end{array}$ & $\begin{array}{c}13.33 \\
(21.14)\end{array}$ \\
\hline Bedana Sedana $\left(\mathbf{R}_{10}\right)$ & $\begin{array}{c}14.00 \\
(21.97)\end{array}$ & $\begin{array}{c}33.33 \\
(35.22)\end{array}$ \\
\hline Daru $\left(\mathbf{R}_{11}\right)$ & $\begin{array}{c}16.00 \\
(23.58)\end{array}$ & $\begin{array}{c}16.67 \\
(23.86)\end{array}$ \\
\hline SE m ( $( \pm)$ & 0.19 & 2.90 \\
\hline CD at $5 \%$ & 0.57 & 8.51 \\
\hline
\end{tabular}

* Figures in parenthesis are arc-sine value 
Table.2 Reaction of different rootstocks to nematode, Meloidogyne incognita at $19^{\text {th }}$ month

\begin{tabular}{|c|c|c|c|c|c|}
\hline \multirow[t]{2}{*}{ Treatment } & \multirow[t]{2}{*}{$\begin{array}{c}\text { No. of } \\
\text { roots/plant }\end{array}$} & \multirow{2}{*}{$\begin{array}{c}\text { No. of nematode } \\
\text { galls/egg masses } \\
\text { /plant }\end{array}$} & \multicolumn{2}{|c|}{$\begin{array}{l}\text { Root-knot nematode } \\
\text { population /pot }\end{array}$} & \multirow[t]{2}{*}{$\begin{array}{c}\text { Reaction to } \\
\text { nematode }\end{array}$} \\
\hline & & & Initial & Final & \\
\hline \multicolumn{6}{|l|}{ Rootstocks } \\
\hline Ganesh $\left(\mathbf{R}_{1}\right)$ & $\begin{array}{c}15.33 \\
(23.04)\end{array}$ & $\begin{array}{c}32.00 \\
(34.44)\end{array}$ & 500 & 5450.00 & $\mathbf{S}$ \\
\hline Bedana Suri $\left(\mathbf{R}_{2}\right)$ & $\begin{array}{c}16.00 \\
(23.58)\end{array}$ & $\begin{array}{c}28.67 \\
(32.37)\end{array}$ & 500 & 3833.33 & MR \\
\hline Alandi ( $\left.\mathbf{R}_{3}\right)$ & $\begin{array}{c}16.00 \\
(23.58)\end{array}$ & $\begin{array}{c}32.67 \\
(34.86)\end{array}$ & 500 & 5233.33 & $\mathbf{S}$ \\
\hline Kandhari $\left(\mathbf{R}_{\mathbf{4}}\right)$ & $\begin{array}{c}15.00 \\
(22.79)\end{array}$ & $\begin{array}{c}31.33 \\
(34.04)\end{array}$ & 500 & 5860.00 & $\mathbf{S}$ \\
\hline $\begin{array}{c}\text { Jallore Seedless } \\
\left(\mathbf{R}_{\mathbf{5}}\right)\end{array}$ & $\begin{array}{c}14.33 \\
(22.24)\end{array}$ & $\begin{array}{c}27.33 \\
(31.52)\end{array}$ & 500 & 3443.33 & MR \\
\hline Jodhpur Red $\left(\mathbf{R}_{6}\right)$ & $\begin{array}{c}14.67 \\
(22.50)\end{array}$ & $\begin{array}{c}26.00 \\
(30.66)\end{array}$ & 500 & 3996.67 & MR \\
\hline Patna-5 $\left(\mathbf{R}_{7}\right)$ & $\begin{array}{c}14.00 \\
(21.97)\end{array}$ & $\begin{array}{c}34.67 \\
(36.07)\end{array}$ & 500 & 5743.33 & $\mathbf{S}$ \\
\hline Muscat $\left(\mathbf{R}_{8}\right)$ & $\begin{array}{c}14.33 \\
(22.24)\end{array}$ & $\begin{array}{c}32.67 \\
(34.86)\end{array}$ & 500 & 5476.67 & $\mathbf{S}$ \\
\hline Yercaud ( $\left.\mathbf{R}_{9}\right)$ & $\begin{array}{c}14.00 \\
(22.97)\end{array}$ & $\begin{array}{c}36.00 \\
(36.87)\end{array}$ & 500 & 5630.00 & $\mathbf{S}$ \\
\hline $\begin{array}{c}\text { Bedana Sedana } \\
\left(\mathbf{R}_{10}\right)\end{array}$ & $\begin{array}{c}14.00 \\
(22.97)\end{array}$ & $\begin{array}{c}34.00 \\
(35.67)\end{array}$ & 500 & 5433.33 & $\mathbf{S}$ \\
\hline $\operatorname{Daru}\left(\mathbf{R}_{11}\right)$ & $\begin{array}{c}13.67 \\
(21.68)\end{array}$ & $\begin{array}{c}25.33 \\
(30.22)\end{array}$ & 500 & 3286.67 & MR \\
\hline SE m $( \pm)$ & 0.36 & 0.32 & --- & 705.70 & --- \\
\hline CD at $5 \%$ & 1.08 & 0.96 & --- & NS & --- \\
\hline
\end{tabular}

MR- Moderately Resistance S- Susceptible Figures in parenthesis are arcsine value.

The final minimum (3286.67/pot) nematode count was recorded in rootstock Daru $\left(\mathrm{R}_{11}\right)$. However, the maximum (5860.00) nematode count was recorded in the rootstock Kandhari $\left(\mathrm{R}_{4}\right)$

\section{Reaction to nematodes}

According nematode galls numbers; plants are categorized as moderately resistant and susceptible. Rootstocks namely, Daru $\left(\mathrm{R}_{11}\right)$, Jodhpur Red $\left(\mathrm{R}_{6}\right)$, Jallore Seedless $\left(\mathrm{R}_{5}\right)$ and Bedana Suri $\left(R_{2}\right)$ were found to be moderately resistance, while the remaining rootstocks were found to be susceptible (Table 2). Within moderately resistant group, higher plant survival percentage was recorded. None of the rootstock was resistant to the nematodes infestation. During the present study, nematode inoculated plants showed complete drying and wilting after 18 months. Identification of either nematode tolerant/resistant rootstocks will be helpful in long term management of this complex disease phenomenon and a challenge. 
Potted plants (cv. Bhagwa) were inoculated with root-knot nematodes ( $M$. incognita). One plant wilted and exhibited complete drying and browning of the leaves one year after inoculation (Anon., 2014) Wilting of pomegranate plants due to nematode infection is also reported. It indicates that, pathogenicity period varied from 01-12 months after inoculation of pathogen and nematodes.

It means easier/earlier infection of pathogen or nematode is though open area like in cutting or base part of cutting/gooty/on succulent roots. Cutting or gooty provides more exposure to and there by easier infection of pathogen.

During present investigation the wilt symptoms were recorded late (16.33 months) in rootstock Jallore Seedless and it was followed by in rootstock Bedana Suri, Jodhpur Red, and Daru (16.00 months each).

The late wilt symptoms appearance could be attributed to late entry of pathogen in the seedlings/plant. However, the decline symptoms were observed from 12.00-16.33 months. This indicates later infection or later decline in seedlings than cutting or gooty.

Plants exhibiting yellowish foliage, stunted growth and decline may be attributed to penetration of Fusarium oxysporum and Meloidogyne incognita in to the roots and its hyphae invaded the xylem vessels, preventing the transport of water and nutrients to other organs of the plant. In present study similar symptoms were recorded and are in accordance with Kore and Mitkar (1993) who described the symptoms of Fusarium root rot of pomegranate wilt caused by Fusarium solani. Somasekhara (1999) who described the symptoms of pomegranate wilt caused by Ceratocystis fimbriata.

The lowest mortality was recorded in rootstocks Bedana Suri and Yercaud (13.33\% each). The highest mortality was recorded in Alandi and Muscat (40.00\% each). This could be attributed to rootstocks response for late incubation of pathogen and thus indicates importance of rootstock in management of Fusarium oxysporum and nematodes which is accordance with Van der Plank, (1963) who reported a long incubation period is an important component for host plants to have a partial resistance to a given pathogen.

The rootstock Daru showed least number of nematode galls as compared to other rootstocks. This screening showed that four rootstocks viz., Daru, Jodhpur Red, Jallore Seedless and Bedana Suri showed moderately resistant reaction. Remaining seven rootstocks showed susceptible reactions against root-knot nematodes Meloidogyne incognita and wilt disease and maximum number of nematode galls were observed in the rootstock Yercaud. Results recorded in present study are in accordance with Darekar and Shelke (2000) screened thirty five varieties/lines of pomegranate against root-knot nematodes.

Late wilt symptoms was observed in the rootstocks viz., Jallore Seedlees, Bedana Suri, Jodhpur Red, and Daru.

Lowest mortality was observed in the rootstocks viz., Bedana Suri, Yercaud, Daru and Jallore Seedless.

Minimum number of root-knot nematode gall was recorded in rootstock Daru.

The rootstocks viz., Daru, Jodhpur Red, Jallore Seedless and Bedana Suri were found to be moderately resistant to root-knot nematodes Meloidogyne incognita.

The rootstocks viz., Daru, Jodhpur Red, Jallore Seedless and Bedana Suri were found to be moderately resistant to root-knot nematode. 
Thus, the use of moderately resistant rootstocks could be helpful in long term management of pomegranate wilt.

\section{References}

Anonymous, 2014. Director, National Research Centre on Pomegranate, Solapur, Annual Report 2013-2014. Plant Protection, pp. 62-64

Cobb, N. A. 1918. Estimating the nema population of the soil. Agric. Tech. Circ. Bur. Pl. Ind. U.S. Dept. Agric. No.1. pp.48.

Darekar, K.S. and S. S. Shelke, 2000. Reaction of some pomegranate germplasm to $M$. incognita. J.
Maharashtra Agric. 25(3): 308-310.

Kore, S. S. and P. L. Mitkar, 1993. Dry root rot disease of pomegranate incited by Fusarium solani. J. Maharashtra Agric. Univ. 18 (2): 256-258.

Robinson, M. P., Atkinson, H. J. and R. N. Perry, 1987. The influence of soil moisture and storage on mortality, infectivity and lipid utilization of second stage juveniles

Somasekhara, Y. M. 1999. New record of Ceratocystis fimbriata causing wilt of pomegranate in India. Pl. Dis. 83 (4): 400.

Vander Plank, J. E. 1963. Plant Diseases. Epidemics and control. New York NY, USA.

\section{How to cite this article:}

Dipak Kumar B. Ahire. 2021. Screening of Different Rootstocks of Pomegranate (Punica granatum L.) against Root Knot Nematode. Int.J.Curr.Microbiol.App.Sci. 10(06): 288-294.

doi: https://doi.org/10.20546/ijcmas.2021.1006.030 